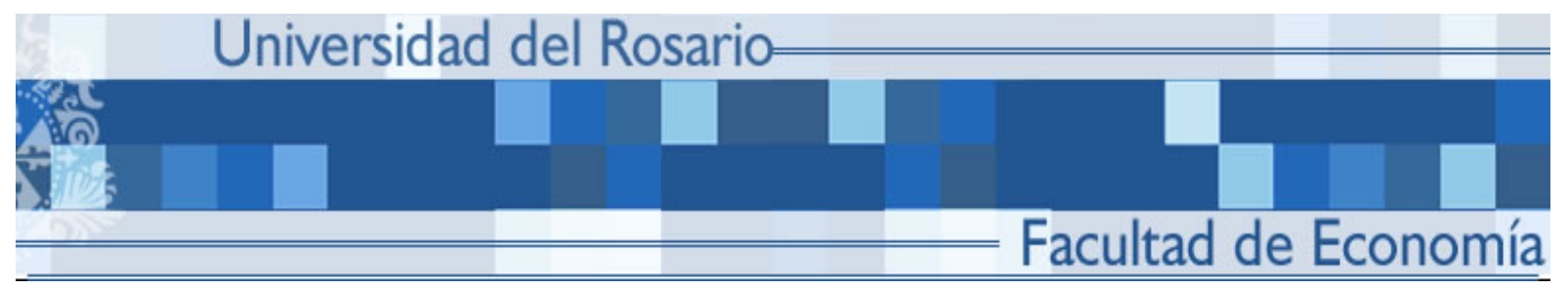

FACTOR SHARES AT THE SECTOR LEVEL, COLOMBIA 1990-2005

Hernando Zuleta

Andrés Garcia-Suaza

Andrew Young

SERIE DOCUMENIOS DE TRABAJ $O$

No. 76

Noviembre 2009 


\title{
FACTOR SHARES AT THE SECTOR LEVEL, COLOMBIA 1990-2005
}

Hernando Zuleta*
Andres Garcia-Suaza

Andrew Young

\begin{abstract}
In general, empirical studies on economics rely on the assumption of constant capital share of income both at the aggregate level and at the sector level. However, there is no empirical evidence supporting the constancy of capital share at the sector level. In this paper, using Colombian data, we measure capital share for 48 sectors during the period 1990-2005. We also explore the relation between capital's share and factor prices and the behavior of capital share during the business cycle. The main results are the following: (i) capital share is not constant but, rather, has an increasing trend; (ii) capital shares growth rates positively correlate with sector value-added growth; (iii) the capital shares behave pro-cyclically; and (iv) there is a positive correlation between capital shares and real wages and a negative correlation between capital shares and interest rates. These results suggest that the usual assumption of constant factor shares is not accurate.
\end{abstract}

JEL classification: E23, E25, O10, O11, O30, O41; O47

Key words: Factor Shares, income distribution, cycles, economic growth, Colombia

* Corresponding Author. Economics Department Brown University and Facultad de Economía. Universidad del Rosario - Bogotá. hernando.zuleta@gmail.com

- Facultad de Economía. Universidad del Rosario - Bogotá. andres.garcia66@urosario.edu.co.

• College of Business and Economics. West Virginia University. Andrew.Young@mail.wvu.edu. 


\section{INTRODUCTION}

The Studies by Cobb and Douglas (1928) and Kaldor (1961) created a paradigm in macroeconomics. The idea that capital share is constant has produced important consequences for macroeconomic theory in general and, in particular, for economic growth theory. If capital share is constant and factor prices are equal to marginal productivities, then the elasticity of output with respect to capital must be constant. (This is likewise for the labor elasticity.) In other words, the Cobb-Douglas production function is a good approximation of the aggregate production function. ${ }^{1}$

Following this paradigm, growth accounting exercises and theoretical growth models assume Cobb-Douglas production functions. ${ }^{2}$ Moreover, this assumption is very common in studies at the sector level (see Kongsamut et al., 2001, Acemoglu and Guerrieri, 2008, Hsieh and Klenow, 2007 among others). However, there is no evidence supporting the assumption of constant capital shares at the sector level.

In this paper we use Colombian data for 48 sectors. The utilization matrices allow us to compute capital shares for every sector every year between 1990 and 2005. These matrices give information about intermediate consumption, factor incomes, taxes, exports and investment.

The first interesting result is that capital shares are not constant at the sector level. Moreover, for several sectors capital shares have a clear trend. This result is consistent with the studies made by Andrew Young (2009) for the U.S. and by Carmen Garrido-Ruiz (2005) for Spain.

The figures from Colombia also show that (1) aggregate capital share has a positive trend starting around 1999; (ii) capital shares grow faster in faster growing sectors; (iii) capital

\footnotetext{
${ }^{1}$ A Cobb-Douglas is a sufficient but not necessary condition for balanced growth in the aggregate so long as technical change in the aggregate is labor-augmenting (Uzawa (1961) and Jones and Scrimgeour (2008)). However, this does imply that aggregate production possibilities asymptotically behave like a Cobb-Douglas. 2 See Solow, 1957, Young, 1994 and Easterly and Levine (2002), among others, for growth accounting and, for growth theory Lucas, 1988 and Romer, 1990 are the most visible contributions.
} 
shares grow faster when the economy as a whole is growing faster; and (iv) the correlations between capital shares and wages are negative. These results have important implications: macroeconomic models should be able to reproduce the trends in capital shares at the sector level and to relate the movements in capital shares with the movements in factor prices and economic growth.

In principle, these results can be consistent with a story where some firms experience productivity shocks and the change in value-added goes partially to workers and partially to capital owners. If the increase (decrease) in capital income is proportionally greater (less) than the increase (decrease) in labor income then wages are positively correlated to capital shares and both are positively correlated to value-added. This is consistent with labor contract/employment insurance models of Gomme and Greenwood (1995) and Boldrin and Horvath (1995): in the presence of insurance, labor income is higher than it would otherwise be during recessions and lower during expansions.

Note also that capital income includes the remuneration to entrepreneurial activities so when entrepreneurs become more successful capital shares should also grow and it is possible to observe the above-mentioned correlations.

Our results are also consistent with the predictions of models of biased innovations. ${ }^{3}$ All else equal, this type of technological change may increase the marginal productivity of the abundant factor(s) realtive to that of the scare factor(s). In this setting, if factor prices are

\footnotetext{
${ }^{3}$ These models where introduced in the 1960s by a group of scholars including Kennedy (1964), Samuelson (1965), Ahmad, S. (1966), Drandakis and Phelps (1966) and Weizsäcker (1966). Recently, several authors provide theoretical growth models where innovations are factor saving and factor shares are not constant. Zeira (1998) presents a model of technological innovations that reduce labor requirements but raise capital requirements and find that technological innovations are not everywhere adopted, but only in countries with high wages. Seater (2005), Zeira (2006), Peretto and Seater (2007) and Zuleta (2008a) among others (see also Boldrin and Levine, 2002 and Acemoglu, 2002), present models where the relative scarcity of a factor generates incentives to adopt technologies that reduce the need for the scarce factor.
} 
equal to the marginal productivities, then factor saving innovations may generate increases in factor shares for abundant factors. ${ }^{4}$

As we stated before, according to the Cobb-Douglas-Kaldor paradigm capital share is constant. The theory of biased innovations, therefore, has implications for capital share may be inconsistent with this paradigm.

Finally, the behavior of capital shares that we report here can be accounted for by assuming CES production functions with elasticity of substitutions between capital and labor higher than one. In the case of an elasticity of substitution greater than unity, as the capital to labor ratio increases, all else equal, capital share will increase.

The main point we want to highlight here is that the assumption of constant shares at the sector level is inaccurate. We also compare our results with the implications of different theories that predict changes in capital shares.

Despite the apparent consensus about the constancy of factor shares our results are not surprising. Other empirical evidence suggests that factor shares are not always constant. ${ }^{5}$ Blanchard (1997) observes that the capital share increases in continental Europe after the 80s and suggests that the reason of such decline may be technological bias. Kahn and Lim (1998) show that the shares of equipment, production workers and non production workers have clear trends.

\footnotetext{
${ }^{4}$ Zeira (2005), Zuleta (2007a) and Zuleta and Young (2007) show that the existence of a labor-intensive services sector where biased technical changes are not common can explain the quasi-horizontal trend in capital share even if technological progress is labor saving in the other sector.

${ }^{5}$ In the 1990s several authors challenged the Cobb-Douglas-Kaldor paradigm. Galí (1994), for example, uses data from the U.N. National Income Accounts publication corresponding to year 1985 and builds measures of labor share for 46 countries. The results suggest that there exists a positive correlation between labor income share and GDP per capita. However, an empirical study by Douglas Gollin (2002) gives new strengths to the Cobb-Douglas-Kaldor paradigm. Gollin calculates labor shares for 31 countries and finds that labor shares are between 0,65 and 0,80 and there is no correlation at all between GDP and factor shares. Finally, Rodriguez and Ortega (2006) make new calculations for the labor share and find that it is positively related to GDP per capita (confirming the result by Galí, 1994).
} 
There have also been some efforts trying to demonstrate that factor shares if measured properly have clear trends. Zuleta (2008b) and Zuleta, Parada and Campos (2008) and Sturgill (2009) explain that the traditional assumption of two factors of production (capital and labor) does not distinguish properly between reproducible and non-reproducible factors. ${ }^{6}$ They claim that physical capital and human capital are reproducible while raw labor and land are non-reproducible and calculate income shares for each of the four factors. Their findings suggest that the income share of reproducible factors, i.e. physical and human capital, is positively related with per capita income. ${ }^{7}$

Other empirical papers have enriched the literature in recent years. Herrendorf and Valentinyi (2006) calculate factor shares for different sectors in the United States and find that it can differ substantially among sectors. Young (2008) shows that that, from 1958 to 1996, U.S. factor shares are not stable at the sector level; furthermore, aggregate factor shares are not more stable than would be expected given sector level volatility.

Our contribution to the literature on capital shares is twofold. First, using Colombian data we calculate capital shares at the sector level for the period 1990-2005. We document differences in capital shares across sectors and test the constant capital share hypothesis for each sector. Second, we compute correlations between capital shares and (a) real wage rates, (b) interest rates, and (c) sector value-added growth rates and try to identify the determinants of capital shares.

The rest of the paper is organized as follows. In the next section we present the data and the results on factor shares. In section 3 we present empirical evidence relating capital shares to sector value-added levels and growth rates; and to factor prices. Finally, concluding comments and discussion are provided in section 4.

\footnotetext{
${ }^{6}$ Caselli and Feyrer (2007) in cross-country study show that the share of reproducible capital is positively correlated to GDP per capita.

${ }^{7}$ The papers by Zuleta (2008) and Sturgill (2009) provide a data for different countries while the paper by Zuleta, Parada and Campo (2008) is limited to the Colombian case.
} 


\section{DATA AND METHODOLOGY}

The information we use comes from the set of utilization matrices provided by DANE for the period 1990-2005. These matrices have information about labor supply, intermediate consumption, factors income, exports, investment and government spending for 60 sectors.

For each year and each sector the matrices provide the value-added of the sector as share of GDP, the labor income share and the capital income share. Therefore, we can calculate the contribution of each sector to the changes in aggregate capital share.

In order to have series that are consistent with National Account we have to regroup sectors and reduce their number to 48 .

We define $\alpha$ as the capital income share, that is, gross profits $\left(G P_{i t}\right)$ divided by the GDP of the sector:

$$
\alpha_{i t}=\frac{G P_{i t}}{G D P_{i t}} \quad i=1, \cdots, 48 ; \quad t=1990, \cdots, 2005
$$

\section{A. Capital Shares}

We report the results in Table 1 (A in the Annex). The first column presents the average capital share for the period 1990-2005 for each sector. The second column presents the standard deviation of the sector capital shares $\left(\alpha_{i}^{\prime} \mathrm{s}\right)$. Columns three and four present the sector value-added shares and their standard deviations respectively. (A sector's valueadded share is defined as $y_{i}=G D P_{i} / G D P$.) Finally, the last two columns present the absolute changes in sector capital shares and value-added shares for the period 1990-2005. In Table A we present the results for 48 sectors. $^{8}$

\footnotetext{
${ }^{8}$ The sectors with the biggest capital income share are real state, sectors related to mining and extraction and public services. The sectors with the lowest capital share are personal services, transportation, green coffee and other agricultural products. Along the period, capital shares change substantially in some sectors. In hotels and restaurants the capital share grows almost 40 percent points while in textiles it decreases in 40 points.
} 
Having data for 48 sectors is useful from a statistical point of view (see Table $\mathrm{A}$ in the Annex). However, aggregating into 9 major sectors is more tractable for presentation purposes. Figures 1 and 2 show the evolution of capital shares and relative sizes for the 9 sectors while Table B in the appendix presents the correlation matrices for capital shares and value-added shares.

Financial Services, Mining and Public Services are the most capital-intensive sectors with average capital shares of $0.625,0.618$ and 0.743 respectively from 1990 to 2005. The sectors of the economy where the average capital shares are lowest are Agriculture, Fishing, and Hunting (AFH) and Hotels and Restaurants with 0.052 and 0.180 respectively. Also, between 1990 and 2005 capital shares grow in all sectors but two: AFH and Financial services. Public Services and Construction present the largest increases in capital shares (by 0.230 and 0.174 respectively).

Regarding relative size, Financial Services and AFH are the biggest sectors with over 30\% of the GDP on average between 1990 and 2005. The fastest growing sector over the 1990 to 2005 period is Social, Personal, and Communication Services (SPCS) (about 6 percent); the most rapidly shrinking sector is AFH (about 6 percent). Every other value-added share changed by less than 3 percent in absolute value.

Table 1.Aaverage and standard deviation of capital share and value-added share (9 sectors)

\begin{tabular}{lccccccc}
\hline \multicolumn{1}{c}{ Sector } & $\bar{\alpha}$ & $s . e(\alpha)$ & $\bar{y}$ & $s . e(y)$ & $\Delta \alpha$ & $\Delta y$ \\
\hline Agriculture, Fishing and Hunting & 0.052 & 0.005 & 0.141 & 0.020 & -0.009 & -0.058 \\
Mining & 0.618 & 0.096 & 0.052 & 0.013 & 0.014 & -0.010 \\
Public Services & 0.743 & 0.076 & 0.037 & 0.007 & 0.230 & 0.020 \\
Manufacturing & 0.487 & 0.030 & 0.156 & 0.013 & 0.042 & -0.028 \\
Construction & 0.467 & 0.067 & 0.055 & 0.014 & 0.174 & 0.023 \\
Commerce, restaurants and Hotels & 0.180 & 0.021 & 0.118 & 0.009 & 0.086 & -0.024 \\
Transportation, storage and communication & 0.274 & 0.047 & 0.075 & 0.004 & 0.117 & 0.016 \\
Financial Services & 0.625 & 0.045 & 0.167 & 0.014 & -0.068 & 0.000 \\
Social, Personal and Communal Services & 0.230 & 0.008 & 0.199 & 0.033 & 0.005 & 0.062 \\
\hline
\end{tabular}

Source: Authors' estimations 
Figure 1 Capital Shares, 9 sectors

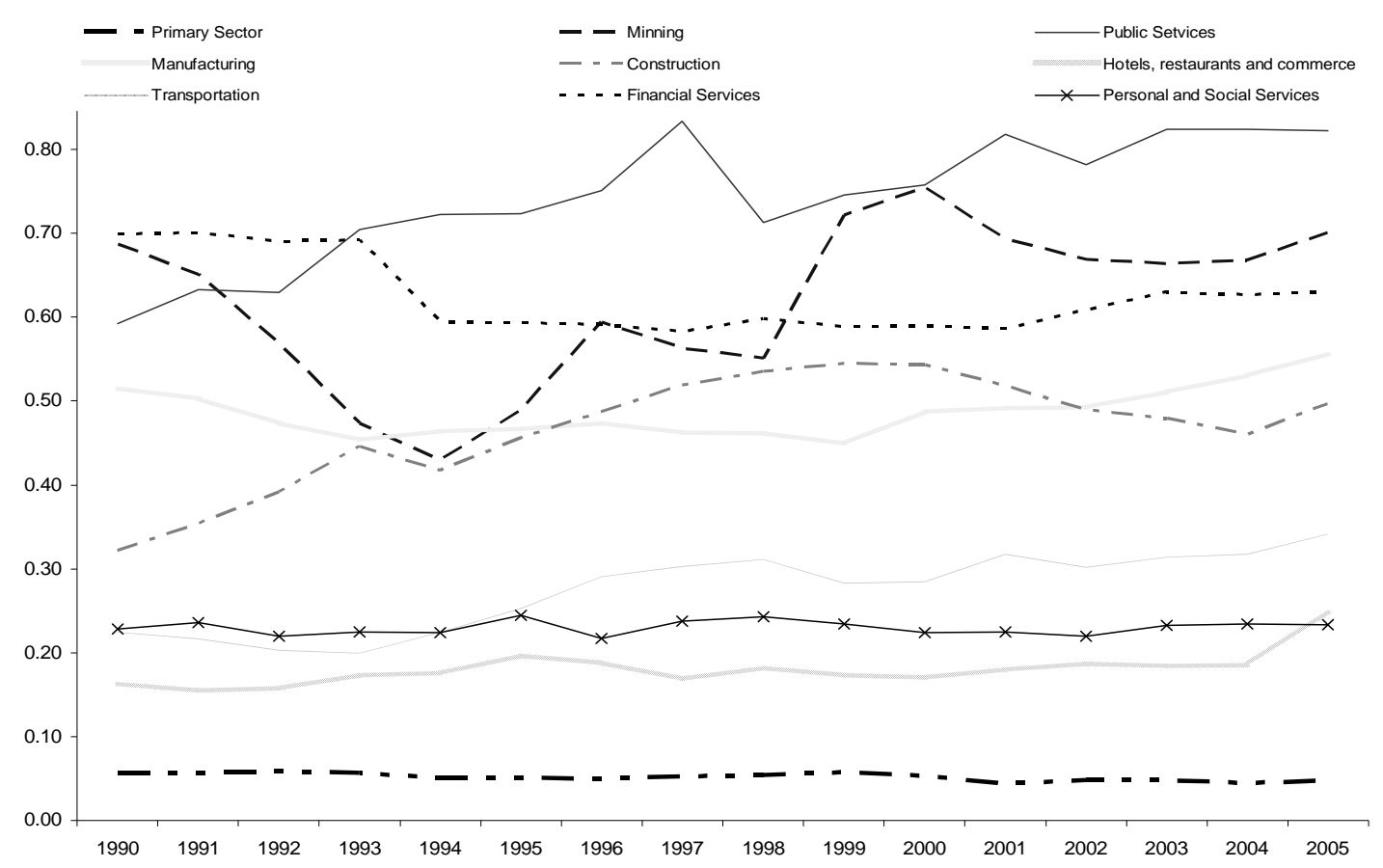

Source: Authors' estimations

Figure 2 Value-Added Shares, 9

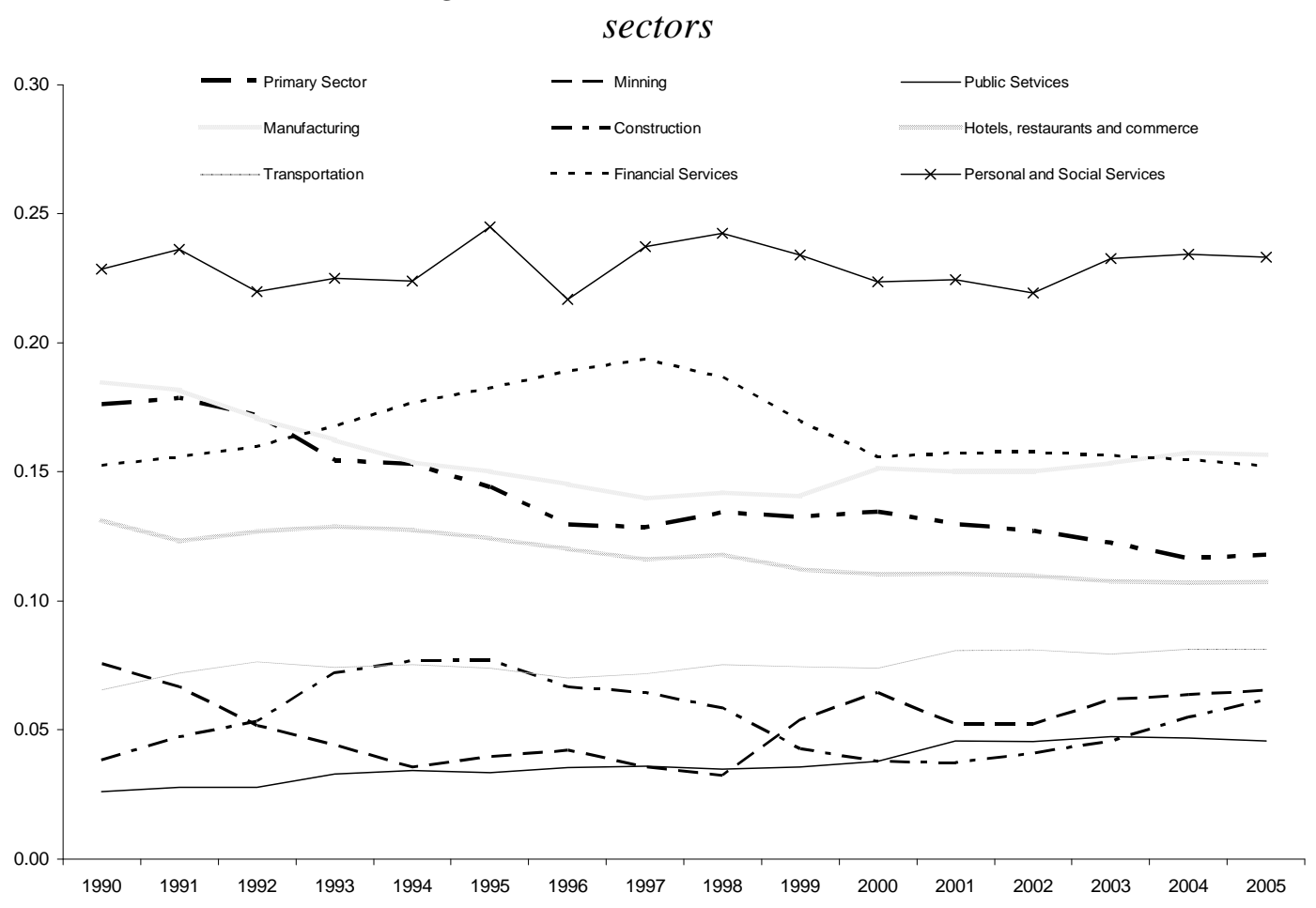

Source: Authors' estimations 
Another interesting fact is that, in general, the sectors where the value-added growth rate is higher contribute to increase the aggregate labor's share (i.e., either they have a high labor share or a growing labor share) while for the sectors where the value-added growth rate is lower contribute to decrease the aggregate labor's share. This "big picture" is made visible in Figure 3: sectors where value-added grows faster contribute positively to aggregate labor's share while sectors where the value-added grows slower contribute negatively to aggregate labor's share.

This result is similar to that obtained by Zuleta and Young (2009) and suggests that the theoretical model they propose may be accurate for Colombia. According to their theory, there are sectors where the elasticity of substitution between factors is lower than one such that, as the economy becomes more abundant in capital, labor share grows in these sectors. However there are other sectors where technological growth is biased so that, as the economy becomes more abundant in capital, the labor share in those sectors decreases.

Figure 3. Change in Value-Added Shares VS Contribution to Change in Aggregate Labor Share

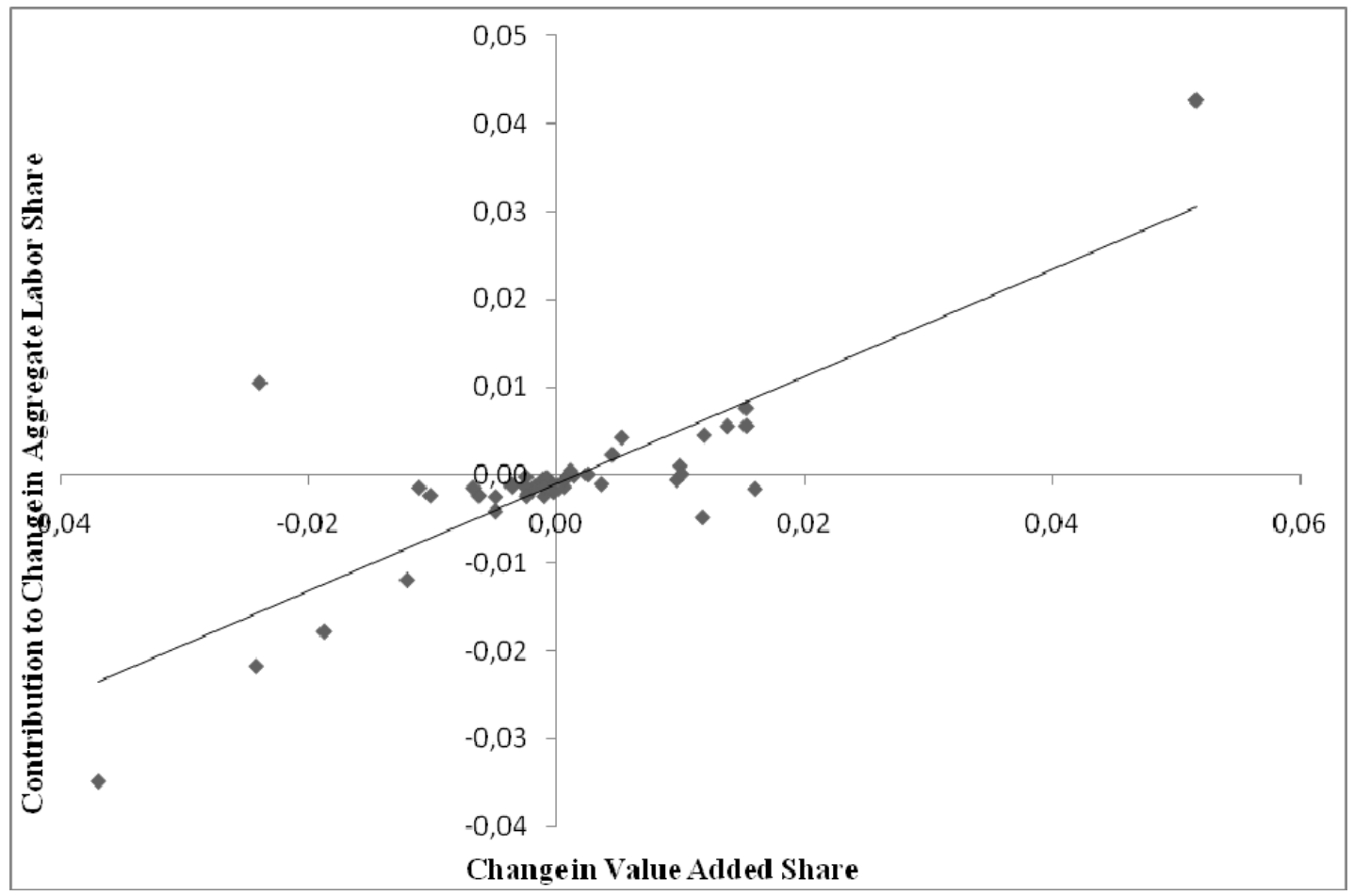


Source: Authors' estimations

\section{B. Aggregate Capital Share}

Calculations of aggregate capital shares are subject to various criticisms. In particular, assumptions about what part of the income of the self-employed is labor income and what part is capital income can be controversial. The case of Colombia is not an exception. Moreover, in National Accounts before 1994 the income of self-employed people was considered labor income so it is not possible identify the income of self-employed before this year. ${ }^{9}$

Using the utilization matrices data it is possible to calculate aggregate factor shares. Of course, we are not considering the income of self employed people and we are not considering the informal sector. This fact can introduce a bias in our estimation of the aggregate capital share. If the informal sector is more labor intensive than the formal sector we may be underestimating aggregate labor share. However, this bias does not affect the main conclusion of the paper: factor shares are not constant at the sector level (at least for the formal sector).

We know the capital shares and value-added shares of every sector so we can calculate the aggregate capital share as a weighted average:

$$
\alpha_{t}=\sum_{i=1}^{48} \alpha_{i t} y_{i t} \quad t=1990, \cdots, 2005
$$

where $\alpha_{i}$ and $y_{i}$ are, again, the sector capital shares and value-added shares respectively.

The aggregate capital share in 1990 is 0.362 and it rises to 0.407 by 2005 (an increase of 0.045). From Figure 4, it is clear that between 1990 and 1999 aggregate capital share does not have a trend upward or downward, but between 1999 and 2005 it has a positive trend.

\footnotetext{
${ }^{9}$ Zuleta, Parada and Campo (2008) make estimations using different assumptions and they find the same trends we find in this paper.
} 
The behavior of capital shares in consistent with the behavior of the economy in the last years, high growth rates and high unemployment, that is, jobless growth.

Finally, the empirical evidence suggests that, for the case of Colombia, capital shares are not constant at either at the sector level or at the aggregate level.

\section{Decomposing the variance of capital shares}

Using the capital share data at the sector level we calculate the contribution of each sector to the variance of the aggregate capital share. The standard deviation of the aggregate capital share for the period 1990-1999 is 0.93 points and for the period 2000-2005 it is 1.8 points. Following Foster, Haltiwanger and Krizan (2001) and Young (2009) we decompose the change in capital shares into three components according to,

$$
\Delta \alpha_{t}=\sum_{i} y_{i, t-1} \Delta \alpha_{i, t}+\sum_{i}\left(\alpha_{i, t-1}-\alpha_{t-1}\right) \Delta y_{i t}+\sum_{i} \Delta \alpha_{i t} \Delta y_{i t} \quad t=1991, \cdots, 2005 .
$$

The first term on the right-hand-side of the above equation is the "within-sector" component and it is the contribution of time $t$ sector capital share changes, holding valueadded shares at their $t-1$ values. The second term is the "between-sector" component and is the contribution of time $t$ changes in value-added shares, holding sector capital shares at their $t-1$ values. ${ }^{10}$ Finally, the "covariance" component is the contribution arising from the co-movement between sector capital shares and value-added shares.

\footnotetext{
${ }^{10}$ More precisely: "holding industry deviations from aggregate capital share at their $t-1$ values."
} 
Figure 4 Aggregate Capital Share.

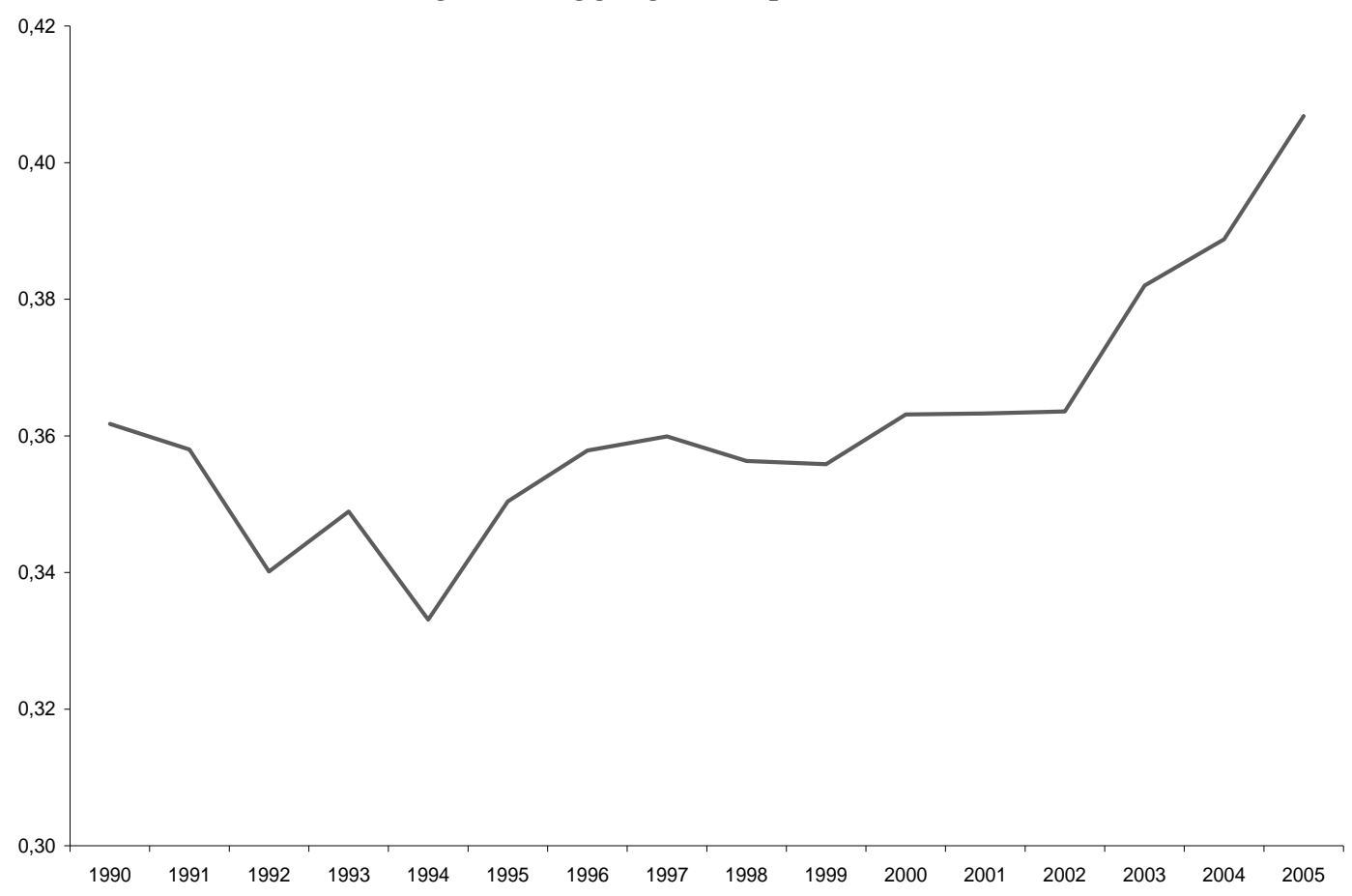

Source: Authors' estimations

The results are presented in figure 5. Between 1991 and 1995 there is a decrease in the capital income share in many sectors. However, the change in the relative sizes of the sectors favors capital intensive sectors so the aggregate capital share remains roughly constant. Between 1995 and 2005, however, capital shares grow in many sectors while the change in sector value-added shares have negligible effects on aggregate capital. (This is evidenced in figure 5 by the importance of the "within-sector" component post-1999 and the small values of both the "between-sector" and "covariance" components. Therefore, during the period aggregate capital share grows. 
Figure 5. Decomposing the variance of capital shares (48 sectors)

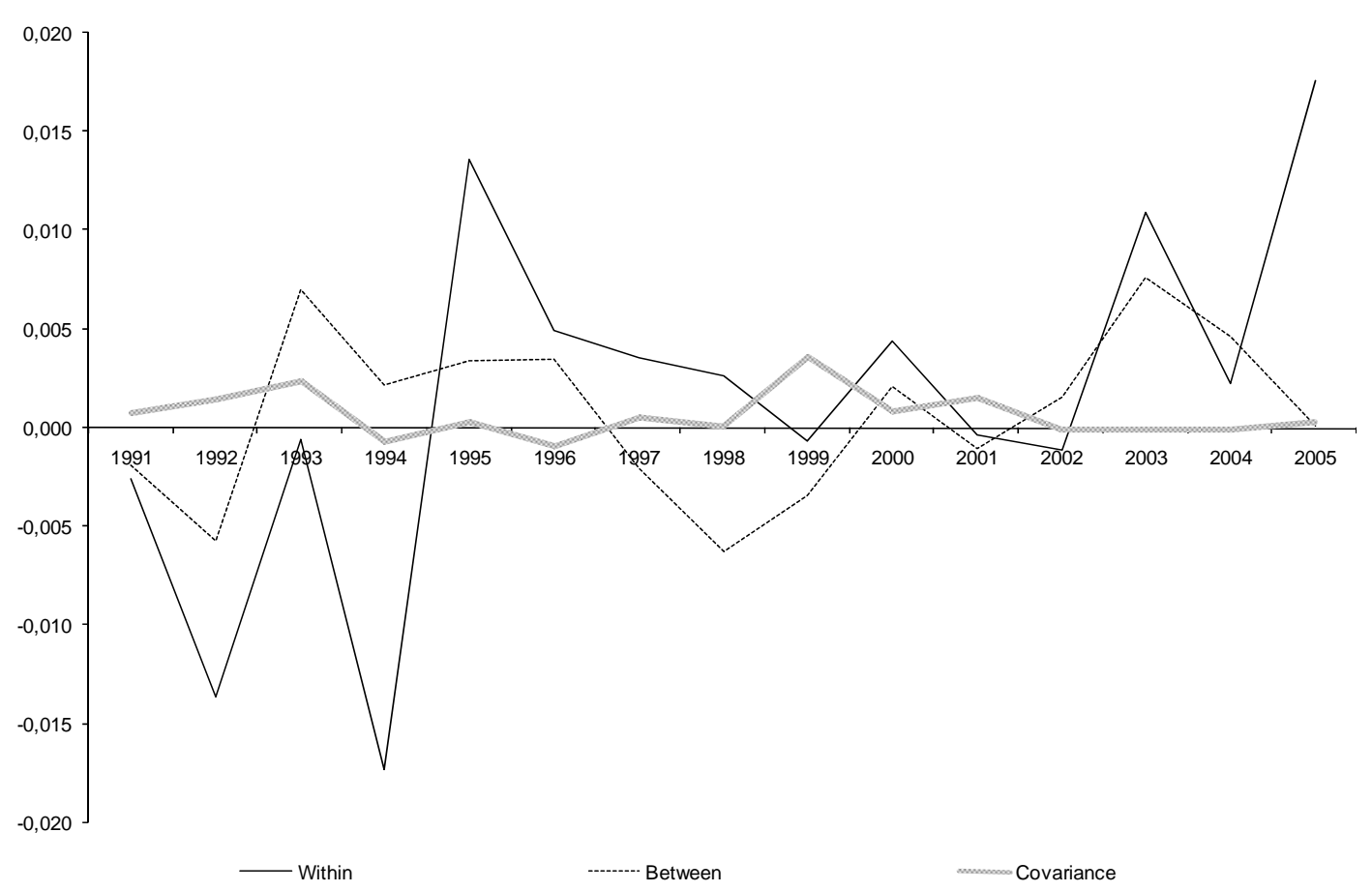

Source: Authors' estimations

\section{CYCLE AND CAPITAL SHARES}

We present the real growth rates of GDP together with the changes in capital income share in Figure 6. The positive correlation between the two variables is apparent. As stated before, this positive correlation may be interpreted in different ways: (i) the recent episodes of economic growth are explained (at least partially) by the adoption of capital intensive technologies; (ii) the cycle is driven by shocks that affect more than proportionally the compensation for entrepreneurial activities (or less than proportionately the remuneration to labor); or (iii) at the sector level the elasticity of substitution between capital and labor is greater than one. (Note that a story based on wage rigidity would be a specific case of case (ii).) We can abbreviate these possibilities as, respectively, (i) "biased innovation”, (ii) “cyclical factor compensation”, and (iii) “above-unity EOS” stories. 
In the following section we provide some additional evidence, at the sector level, that may shed some light to the discussion.

\section{CAPITAL SHARES, FACTOR PRICES AND GROWTH.}

As we stated before, if factor markets are competitive then the capital share depends on technological parameters and on the relative abundance of factors. In this setting, changes in capital share can be produced by technological changes or by changes in the relative abundance of capital. However, the elasticity of substitution between factors of production can differ from one sector to other and the adoption of new technologies may not be equally easy in all sectors. Below we outline some testable implications of the various interpretations of the positive correlation between GDP growth and the changes in capital share.

\section{A. Biased Innovation}

According to the theory of induced innovations firms try to reduce the need of scarce or expensive factors and use abundant or inexpensive factors more intensively. If this theory is correct, capital shares should be positively correlated to lagged wages and negatively correlated to lagged interest rates (see Zeira, 1998). Finally, given that biased innovations increase the return to capital, sectors where the capital share grows are likely to grow faster.

Note also that, if the change in capital shares is explained by technological change then, in the presence of economies of scale, factor shares should grow faster in bigger sectors. In other words, there can be mutual causality: technological change generates increases in capital shares and growth generates incentives for further technological changes. 
Figure 6. Economic Growth and changes in capital income share.

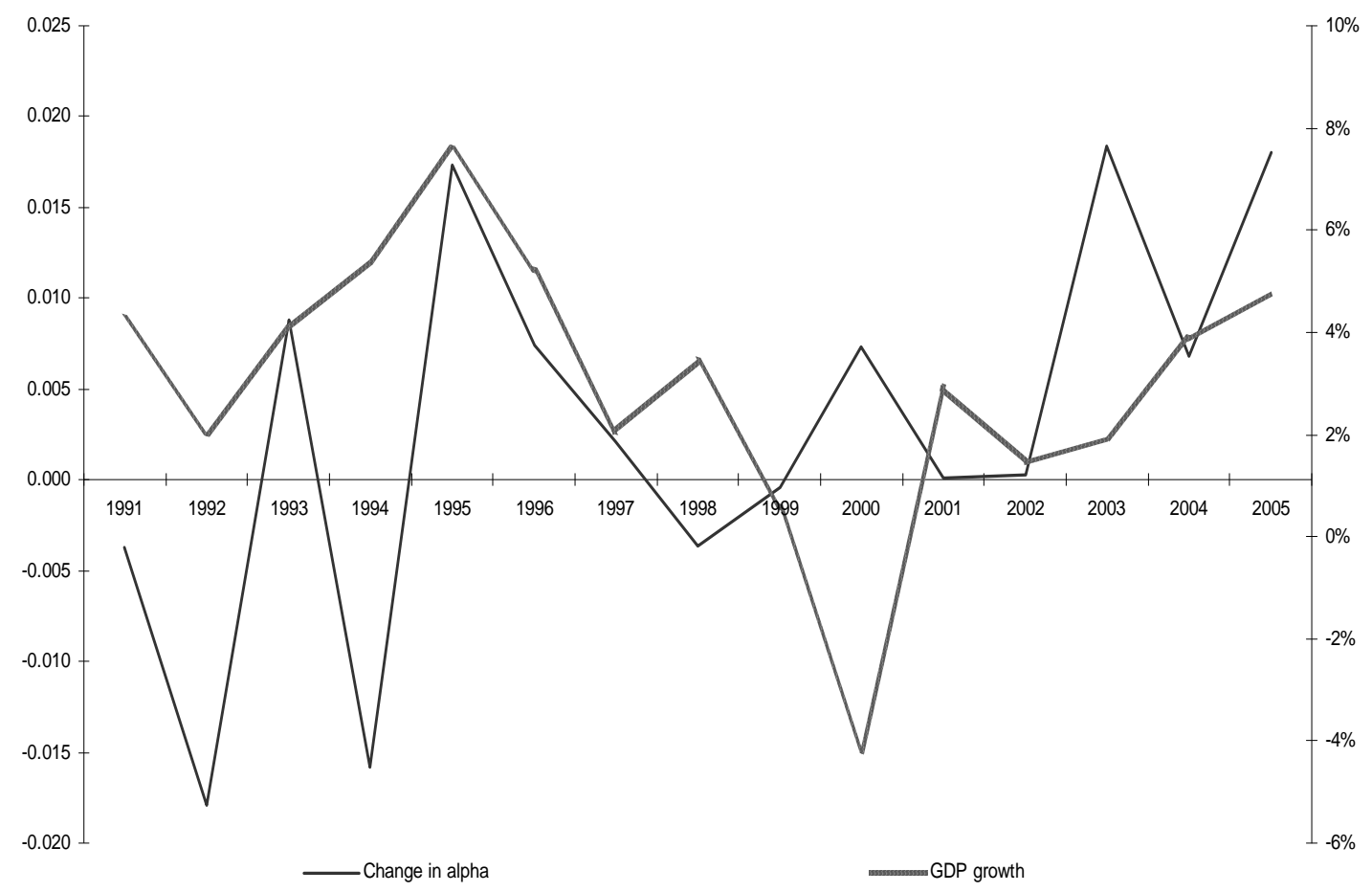

Source: Authors’ estimations

\section{B. Cyclical Factor Compensation}

If production responds to shocks while remuneration of capital is more elastic than that of labor then, all else equal, capital shares will be positively correlated to the current factor price ratio with the wage rate in the numerator. Wage rigidity stories and the presence of private employment insurance are specific examples of the above scenario.

\section{Above-Unity EOS}

Growth in a sector is often associated with increases in the capital to labor ratio over time. For sectors where the elasticity of substitution between labor and capital is higher than one, capital shares should be positively correlated to the capital to labor ratio. (Likewise, for sectors where the elasticity is lower than one this correlation should be negative.) 
We use the available data in order to see first, if there is a direct relation between factor prices and factor income shares, if bigger sectors have higher capital income shares, if the behavior of capital shares is different for different sectors and finally we include lagged values for the independent variables.

We run six different regressions; in all of them the dependent variable is the capital share and the independent variables are value added, wages and interest rates. The results are presented in Table 2. The first column presents the results of a pool model; the second column presents the results of panel model with random effects, column 3 presents the results of panel model with fixed effects, in column 4 we consider the variable relative factor price (wage and interest are not included separately). Finally, the last two columns include lagged values for factor prices.

\section{Variable Definitions}

\begin{tabular}{ll}
\hline \multicolumn{1}{c}{ Variable } & \multicolumn{1}{c}{ Definition } \\
\hline Alpha, $\alpha$ & Capital Income Share - sectoral level \\
\hline Value Added, $V A$ & Value Added - sectoral level \\
\hline Relative Size, $y$ & $\begin{array}{l}\text { Value-added shares: Sectoral Value Added over } \\
\text { aggregate GDP }\end{array}$ \\
\hline Interest Rate & \begin{tabular}{l} 
Time Deposits Interest Rate (90 days) \\
\hline Log(Wage)
\end{tabular} \\
\hline $\begin{array}{l}\text { Logarithm of the real monthly wage for full time } \\
\text { employed. Obtained from Household Surveys. } \\
\text { Prices }\end{array}$ & $\begin{array}{l}\text { Logarithm of the real monthly wage over the } \\
\text { interest rate. }\end{array}$ \\
\hline
\end{tabular}


Table 2 Factor Shares Determinants

\begin{tabular}{|c|c|c|c|c|c|c|}
\hline & $\begin{array}{l}\text { Pool } \\
\text { (1) }\end{array}$ & $\begin{array}{c}\text { Random } \\
\text { Effects } \\
\text { (2) }\end{array}$ & $\begin{array}{c}\text { Fixed } \\
\text { Effects } \\
(3) \\
\end{array}$ & $\begin{array}{c}\text { Fixed } \\
\text { Effects } \\
(4) \\
\end{array}$ & $\begin{array}{c}\text { Fixed } \\
\text { Effects } \\
(5) \\
\end{array}$ & $\begin{array}{c}\text { Fixed } \\
\text { Effects } \\
(6) \\
\end{array}$ \\
\hline Value added & $\begin{array}{c}-1.25 \mathrm{e}-08^{\star \star \star} \\
(4.70 \mathrm{e}-09)\end{array}$ & $\begin{array}{c}5.28 \mathrm{e}-09 \\
(5.63 \mathrm{e}-09) \\
\end{array}$ & $\begin{array}{c}7.13 \mathrm{e}-09 \\
(5.90 \mathrm{e}-09) \\
\end{array}$ & $\begin{array}{c}7.17 \mathrm{e}-09 \\
(5.89 \mathrm{e}-09)\end{array}$ & $\begin{array}{c}6.80 \mathrm{e}-09 \\
(5.76 \mathrm{e}-09) \\
\end{array}$ & $\begin{array}{c}6.36 \mathrm{e}-09 \\
(5.76 \mathrm{e}-09)\end{array}$ \\
\hline Log(Wage) & $\begin{array}{c}1.57 \mathrm{e}-07 \\
(1.26 \mathrm{e}-07)\end{array}$ & $\begin{array}{l}1.21 \mathrm{e}-07^{\star \star \star} \\
(3.81 \mathrm{e}-08)\end{array}$ & $\begin{array}{l}1.17 \mathrm{e}-07^{\star \star \star} \\
(3.83 \mathrm{e}-08)\end{array}$ & & $\begin{array}{l}1.45 \mathrm{e}-07^{\star \star \star} \\
(3.96 \mathrm{e}-08)\end{array}$ & \\
\hline Interest Rate & $\begin{array}{l}-0.114 \\
(0.246)\end{array}$ & $\begin{array}{c}-0.103 \\
(0.0713) \\
\end{array}$ & $\begin{array}{c}-0.102 \\
(0.0713) \\
\end{array}$ & & $\begin{array}{l}-0.202^{\star \star \star} \\
(0.0684)\end{array}$ & \\
\hline Log(relative factor prices) & & & & $\begin{array}{c}0.0824^{* * *} \\
(0.0246)\end{array}$ & & $\begin{array}{l}0.110^{\star * *} \\
(0.0257)\end{array}$ \\
\hline Constant & $\begin{array}{l}0.294^{\star \star \star} \\
(0.0959) \\
\end{array}$ & $\begin{array}{l}0.293^{\star \star \star} \\
(0.0445) \\
\end{array}$ & $\begin{array}{l}0.293^{\star \star \star} \\
(0.0278) \\
\end{array}$ & $\begin{array}{c}-0.737^{\star *} \\
(0.325) \\
\end{array}$ & $\begin{array}{l}0.288^{\star \star \star} \\
(0.0276) \\
\end{array}$ & $\begin{array}{c}-1.107^{\star \star \star} \\
(0.340) \\
\end{array}$ \\
\hline $\begin{array}{l}\text { Observations } \\
\text { R-squared }\end{array}$ & $\begin{array}{c}768 \\
0.011\end{array}$ & $\begin{array}{c}768 \\
0.011\end{array}$ & $\begin{array}{c}768 \\
0.024\end{array}$ & $\begin{array}{c}768 \\
0.023\end{array}$ & $\begin{array}{c}720 \\
0.039\end{array}$ & $\begin{array}{c}720 \\
0.035\end{array}$ \\
\hline
\end{tabular}

Robust standard errors in parentheses

${ }^{* * *} \mathrm{p}<0.01,{ }^{* *} \mathrm{p}<0.05,{ }^{*} \mathrm{p}<0.1$

Source: Authors' estimations

With the exception of model one, the coefficient on value-added is not significantly different from zero and the coefficient on wage is positive for current and lagged levels. The coefficient of the interest rate is not significantly different from zero but the coefficient of the lagged interest rate is negative. Finally, the coefficients of relative factor prices and lagged relative factor prices are positive (relative factor prices is the ratio with the wage rate in the numerator.)

In principle, these results can be consistent with any interpretation from (i) through (iii). However, given that the coefficient of the current interest rate is not significantly different from zero and the coefficient of the lagged interest rate is negative and significant, the evidence goes in favor of biased innovation models.

Now, it can be the case that different sectors have different elasticity of substitution between factors or, more generally, that different sectors react in different ways to changes in factor prices (see Zuleta and Young, 2009). For this reason we run an additional set of regression trying to identify if relative factor prices affect factor shares in different ways for 
different sectors. We aggregate the economy into seven sectors: ${ }^{11}$ Agriculture and Mining, Utilities, Manufacturing, Construction, Trade and Transportation, Financial Services and Social Services, and included multiplicative dummies for these 7 sectors. Table 3 shows the results. Columns 1 and 2 include value added in Logs, columns 3 and 4 include Value Added in levels; columns 1 and 3 include current factor prices and columns 2 and 4 include lagged factor prices.

Table 3. Factor Shares Determinants

\begin{tabular}{lcccc}
\hline & $\begin{array}{c}\text { Fixed Effects } \\
(\mathbf{1})\end{array}$ & $\begin{array}{c}\text { Fixed Effects } \\
(\mathbf{2})\end{array}$ & $\begin{array}{c}\text { Fixed Effects } \\
(\mathbf{3})\end{array}$ & $\begin{array}{c}\text { Fixed Effects } \\
(\mathbf{4})\end{array}$ \\
\hline Value added & $0.174^{\star \star \star}$ & $0.159^{\star \star \star}$ & $1.14 \mathrm{e}-08^{\star \star}$ & $1.19 \mathrm{e}-08^{\star \star}$ \\
& $(0.0193)$ & $(0.0167)$ & $(5.23 \mathrm{e}-09)$ & $(5.25 \mathrm{e}-09)$ \\
\hline Log(relative factor prices) & $-0.131^{\star \star \star}$ & -0.0495 & 0.00775 & $0.0640^{\star}$ \\
Agriculture and Mining & $(0.0371)$ & $(0.0355)$ & $(0.0331)$ & $(0.0377)$ \\
\hline Log(relative factor prices) & $0.430^{\star \star \star}$ & $0.351^{\star \star \star}$ & $0.544^{\star \star \star}$ & $0.448^{\star \star \star}$ \\
Utilities & $(0.0550)$ & $(0.0626)$ & $(0.0548)$ & $(0.0634)$ \\
\hline Log(relative factor prices) & 0.0137 & $0.106^{\star \star}$ & $0.0856^{\star}$ & $0.150^{\star \star \star}$ \\
Manufacturing & $(0.0457)$ & $(0.0456)$ & $(0.0481)$ & $(0.0498)$ \\
\hline Log(relative factor prices) & $0.166^{\star \star \star}$ & $0.122^{\star \star}$ & $0.222^{\star \star \star}$ & $0.145^{\star}$ \\
Construction & $(0.0497)$ & $(0.0484)$ & $(0.0812)$ & $(0.0768)$ \\
\hline Log(relative factor prices) & -0.0316 & -0.0176 & 0.0761 & 0.0680 \\
Trade and Transportation & $(0.0623)$ & $(0.0615)$ & $(0.0706)$ & $(0.0707)$ \\
\hline Log(relative factor prices) & -0.162 & -0.133 & 0.100 & 0.102 \\
Financial services & $(0.107)$ & $(0.118)$ & $(0.122)$ & $(0.135)$ \\
\hline Log(relative factor prices) & $-0.199^{\star \star}$ & $-0.200^{\star \star}$ & -0.0898 & -0.101 \\
Social services & $(0.0833)$ & $(0.0877)$ & $(0.0962)$ & $(0.102)$ \\
\hline Constant & $-1.577^{\star \star \star}$ & $-2.053^{\star \star \star}$ & $-0.669^{\star}$ & $-1.021^{\star \star \star}$ \\
\hline Observations & $(0.316)$ & $(0.326)$ & $(0.373)$ & $(0.385)$ \\
\hline R-squared & 768 & 720 & 768 & 720 \\
\hline
\end{tabular}

Robust standard errors in parentheses

$* * * \mathrm{p}<0.01, * * \mathrm{p}<0.05, * \mathrm{p}<0.1$

Source: Authors' estimations

\footnotetext{
${ }^{11}$ We also run regressions with sector dummies for the 48 sectors. The results, presented in Table $\mathrm{C}$ in the appendix show that within the aggregated sectors there is heterogeneity.
} 
For Construction and Utilities the coefficient of relative factor prices is positive and significant and in all the models. For Manufacturing, the coefficient is positive for all the models but is not significant in model 1. For Social Services, the coefficient is negative for all the models but is not significant in models 2 and 3. For Agriculture and Mining the coefficient is negative for models one and 2 but is not significant in model 2 and it is positive in models 3 and 4 but is not significant in model 4 . Finally, for Trade and Transportation and Financial Services the coefficient is not significant in none of the models.

These results imply that we can not reject the hypotheses of CES production functions or biased innovations in the sectors of Utilities, Manufacturing and Construction. However, given the correlation between current and past factor prices from the previous results we do not have evidence in favor of the CES and against the biased innovation story nor the other way around. In order to solve this problem we run a dynamic panel where the independent variable is the change in the capital income share. We show the results in Table 4.

The model predicts a positive relation between the growth of lagged wages and the change in capital shares, a negative relation between the change in lagged interest rate and the change in capital shares, a positive relation between the change sector size shares and the change capital shares and no significant correlation between change in value added and the change in capital shares. Note also that the coefficients of the current factor prices are not significantly different from zero. Finally, note that the coefficient of the lagged change in capital share is positive and significant. So the sectors where the factor the capital share grows are likely to experiences further increases in the capital share. Therefore, these results support the theory of biased innovations. As economies accumulate capital they have more incentives to use capital intensive technologies; as they increase the capital intensity of the technology they have incentives to accumulate capital in such a way that you have a positive correlation between present a future changes in the capital share. 
Table 4 Factor Shares Determinants- Dynamic Panel

\begin{tabular}{|c|c|c|c|}
\hline & (1) & (2) & (3) \\
\hline \multirow{2}{*}{ Diff Alpha (-1) } & $0.619 * \star \star$ & $0.644^{* \star *}$ & $0.638^{\star * \star}$ \\
\hline & $(0.0654)$ & $(0.0663)$ & $(0.0709)$ \\
\hline \multirow{2}{*}{ Diff Value Added } & 3.83E-08 & $4.3 E-08^{*}$ & 4.87E-08* \\
\hline & (2.58E-08) & $(2.58 E-08)$ & (2.77E-08) \\
\hline \multirow{2}{*}{ Diff Value Added (-1) } & $-2.17 \mathrm{E}-08$ & $-3.1 E-08^{\star}$ & $-3.08 E-08^{\star}$ \\
\hline & (1.61E-08) & (1.81E-08) & $(1.8 \mathrm{E}-08)$ \\
\hline \multirow{2}{*}{ Diff Interest Rate } & 0.0027 & & \\
\hline & $(0.0605)$ & & \\
\hline \multirow{2}{*}{ Diff Interest Rate (-1) } & $-0.209 * \star \star$ & & \\
\hline & $(0.0782)$ & & \\
\hline \multirow{2}{*}{ Diff log wage } & -0.0531 & & \\
\hline & $(0.0477)$ & & \\
\hline \multirow{2}{*}{ Diff log wage(-1) } & $0.094^{\star \star \star}$ & & \\
\hline & $(0.0361)$ & & \\
\hline \multirow{2}{*}{ Diff log relative prices } & & -0.0256 & \\
\hline & & $(0.0504)$ & \\
\hline \multirow{2}{*}{ Diff log relative prices (-1) } & & $0.0856^{\star \star \star}$ & \\
\hline & & $(0.0390)$ & \\
\hline \multirow{2}{*}{$\begin{array}{l}\text { Diff Log(relative factor prices) } \\
\text { Agriculture and Mining }\end{array}$} & & & $-0.112^{\star \star}$ \\
\hline & & & $(0.0560)$ \\
\hline \multirow{2}{*}{$\begin{array}{l}\text { Diff Log(relative factor prices) (-1) } \\
\text { Utilities }\end{array}$} & & & $-0.244^{\star \star \star}$ \\
\hline & & & -0.0743 \\
\hline \multirow{2}{*}{$\begin{array}{l}\text { Diff Log(relative factor prices) (-1) } \\
\text { Manufacturing }\end{array}$} & & & $0.1493^{\star \star}$ \\
\hline & & & $(0.0683)$ \\
\hline \multirow{2}{*}{$\begin{array}{l}\text { Diff Log(relative factor prices) } \\
\text { Construction }\end{array}$} & & & $-0.189 * \star$ \\
\hline & & & $(0.0799)$ \\
\hline \multirow{2}{*}{ Constant } & 0.0005 & 0.0006 & 0.0005 \\
\hline & $(0.0014)$ & $(0.0014)$ & $(0.0015)$ \\
\hline Wald Test & 190.35 & 193.12 & 430.37 \\
\hline P-value & 0.00 & 0.00 & 0.00 \\
\hline
\end{tabular}

Robust standard errors in parentheses

*** $\mathrm{p}<0.01, * * \mathrm{p}<0.05, * \mathrm{p}<0.1$

Source: Authors' estimations

Now, when we include sector multiplicative dummies we find that the increase in capital share as a result of an increase in the wage interest rate ratio is higher in the Manufacturing sector and lower in Construction, Utilities and Agriculture and Mining. Additionally, for Utilities and Manufacturing the lagged factor prices affect the capital share while for Agriculture and Mining and Construction the current factor prices have this effect. These results suggest that (i) the elasticity of substitution between capital and labor is lower in 
Construction and Agriculture and Mining than in the rest of the sectors (ii) biased innovations are more common in the manufacturing sector. ${ }^{12}$

\section{CONCLUSIONS AND DISCUSSION}

Using data from the utilization matrices for the period 1990-2005 we build the series of capital income shares for 48 sectors. We find that capital shares present substantial changes both at the sector and at the aggregate level. At the aggregate level there is an increasing trend while at the industry level the sectors where capital shares grow are those with the highest growth rates. According to these results, the standard assumption of constant labor shares is inconvenient for empirical works.

We also find that the effect that factor prices have on the capital share is different for different sectors. For some sectors when the relative price of labor grows the capital share decreases while for other sectors the relation between factor shares and factor prices is the opposite. This result can be explained by different elasticity of substitution between capital and labor among sectors or because labor saving innovations are not feasible in all sectors.

As we stated before, there are several theories that can explain movements in capital shares. If wages are fixed within certain periods of time then any increase (decrease) in value added generates an increase (decrease) in capital share. This theory can explain the procyclical behavior of capital shares but cannot explain their long run trends. Indeed, as contracts expire wages can be adjusted so, in the absence of factor saving innovations, factor shares are likely to fluctuate around a horizontal trend.

Another explanation can be that firms with monopoly power adopt neutral innovations that allow them to increase output without increasing wages. If this is the case then neutral innovations cause both increases in value added and capital shares. This theory can also

12 In the case of Utilities, the negative coefficient is difficult to interpret. In principle, the negative coefficient for lagged factor prices imply that as one factor becomes relatively more expensive the firms of the sector use more of this factor, which does not make any sense. 
explain the pro-cyclical behavior of capital shares but this theory cannot account for the correlation between lagged factor prices and capital shares.

It can also be argued that movements in factor shares do not reflect movements in technological parameters. Indeed, if the price of a factor is not equal to its marginal productivity movements in factors shares may be the result of changes in bargaining power or changes in legislation. If this is the case then the increase in capital shares is the result of a decreasing trend in the bargaining power of the workers. This theory can also explain the positive correlation between factor shares and growth. Indeed, holding the rest constant increases in capital shares generate rises in the return to capital and, for this reason, stimulate capital accumulation (see Bertola, 1993 and Zuleta, 2007). However, this theory cannot account for the correlation between wages growth and capital shares growth.

Finally, the behavior of capital shares that we report here can accounted for by assuming CES production functions with elasticity of substitution between capital and labor higher than one. However, as it was the case with monopoly power and neutral innovations, this theory predicts a correlation between current (not lagged) wages and capital shares. 


\section{REFERENCES}

Acemoglu, D. (2002) “Directed Technical Change” The Review of Economic Studies, 69 (4), pp. 781-809.

Acemoglu, D. and V. Guerrieri, (2008) "Capital Deepening and Non-Balanced Economic Growth" Journal of Political Economy, vol. 116, 467-498.

Ahmad, S. (1966) “On the Theory of Induced Invention” The Economic Journal, Vol. 76, No. 302. pp. 344-357.

Blanchard O. J. (1997) "The Medium Run," Brookings Papers on Economic Activity, Economic Studies Program, The Brookings Institution, 28 (1997-2), pp 89-158.

Boldrin , M. and Horvath, M. (1995) "Labor Contracts and Business Cycles” Journal of Political Economy, 103 (5), p.p. 972-1004

Boldrin, M. and Levine, D. K. (2002), "Factor Saving Innovation" Journal of Economic Theory, 105 (1), pp. 18-41.

Caselli, F. and Feyrer, J. (2007) "The Marginal Product of Capital" The Quarterly Journal of Economics, MIT Press, vol. 122(2), 535-568, 05.

Cobb C W y Douglas P H (1928). "A Theory of Production" The American Economic Review, Vol. 18 (Supplement) pp. 139-165

Denison, E.F. (1962) "The sources of economic growth in the United States and the alternatives before us" Committee for Economic Development, Washington, DC.

Drandakis, E. M. and Phelps, E.S.(1966) “A Model of Induced Invention, Growth and Distribution” The Economic Journal, Vol. 76, No. 304., pp. 823-840.

Easterly, W. and Levine, R. (2002). "What have we learned from a decade of empirical research on growth? It's Not Factor Accumulation: Stylized Facts and Growth Models" The World Bank Economic Review, VOL. 15, (2), 177-219. 
Foster, L; Haltiwanger, J and Krizan, C. (2001). "Aggregate productivity growth: lessons from microeconomic evidence”. En: C. Hulten, E. Dean y M. Harper; New developments in productivity analysis. Chicago. University of Chicago Press, 303-363.

Garrido Ruiz, C. (2005) "Are Factor Shares Constant? An Empirical Assessment from a New Perspective" Working Paper, http://www.eco.uc3m.es/temp/jobmarket/jmp_C_Garrido.pdf.

Gollin, D. (2002). “Getting Income Shares Right”, Journal of Political Economy, Vol. 110 No. 2 pp 458-474.

Gomme, P. and Greenwood, J. (1995) “On the Cyclical Allocation of Risk” Journal of Economic Dynamics and Control, 19 (1-2), pp. 91-124.

Heckscher, Eli F. (1919). "The Effect of Foreign Trade on the Distribution of Income”, Ekonomisk Tidskrift.

Herrendorf, B. and Valentinyi, A. (2008) "Measuring Factor Income Shares at the Sector Level " Review of Economic Dynamics 11 (4), pp 820-835

Hsieh, C.T. and Klenow, P. J. (2007) "Relative Prices and Relative Prosperity", American Economic Review, 97, pp 562585.

Jones, Charles I. and Scrimgeour, Dean. "The Steady-State Growth Theorem: A Comment on Uzawa (1961)." Review of Economics and Statistics, November 2008, 90 (1), pp. 180-182.

James A. Kahn, Jong-Soo Lim (1998) "Skilled Labor-Augmenting Technical Progress in U. S. Manufacturing” Quarterly Journal of Economics, Vol. 113, No. 4: 1281-1308.

Charles Kennedy (1964) "Induced Bias in Innovation and the Theory of Distribution" The Economic Journal, Vol. 74, No. 295. pp. 541-547.

Kongsamut, Piyabha, Sergio Rebelo, and Danyang Xie, (2001) "Beyond Balanced G Growth”, Review of Economic Studies, 68, 869-882. 
Peretto, P. F. and Seater, J. (2007), "Factor-Eliminating Technical Change “. Economic Research Initiatives at Duke (ERID) Working Paper No. 17. Available at SSRN: http://ssrn.com/abstract=1270650

Rodríguez, F. and Ortega, D. (2006) "Are capital shares higher in poor countries? Evidence from Industrial Surveys," Wesleyan Economics Working Papers 2006-023, Wesleyan University, Department of Economics.

Samuelson, Paul A. (1965) “A Theory of Induced Innovation along KennedyWeisäcker Lines The Review of Economics and Statistics”, Vol. 47, No. 4. pp. 343-356

Seater, J.J (2005) "Share-Altering Technical Progress." In Economic Growth and Productivity, L. A. Finley, ed., Nova Science Publishers, Hauppage, NY 2005, pp. 59-84

Sturgill, B. (2009)"Cross-country Variation in Factor Shares and its Implications for Development Accounting," Working Papers 09-07, Department of Economics, Appalachian State University.

Uzawa, Hirofumi. "Neutral Inventions and the Stability of Growth Equilibrium." Review of Economic Studies, 1961, 28, pp. 117-124.

von Weizsäcker, C.C. (1966) "Tentative Notes on a Two Sector Model with Induced Technical Progress” The Review of Economic Studies, Vol. 33, No. 3. pp 245-251.

Young, A.T.,(2009) "One of the Things We Know that Ain't So: Is U.S. Labor's Share Relatively Stable?” (April 27, 2006).

Zeira, J. (1998). "Workers, Machines and Economic Growth", The Quarterly Journal of Economics, Vol. 113 No. 4 pp. 1091-1117.

Zeira, J. (2005). "Machines as Engines of Growth", CEPR 2005, Discussion Papers 5429.

Zuleta, H. (2007a). "Why labor income shares seem to be constant?” Journal of International Trade and Economic Development. Vol. 16 No. 4. 
Zuleta, H. (2007b) “Biased Innovations in the Harrod-Domar Model.” Revista de Economía del Rosario, Vol. 10, No. 2

Zuleta, H. (2008a). "Factor Saving Innovations and Factor Income Shares” Review of Economic Dynamics, 11 836-851

Zuleta, H. (2008b). “An Empirical note on Factor Shares” The Journal of International Trade \& Economic Development Vol. 17, No. 3, 379-390

Zuleta, H. and Alberico, S. (2007). "Labor supply, biased technological change and economic growth” Ensayos sobre Política Económica 53, Vol. 25.

Zuleta, H., Parada, J. and Campo, J. (2008).” Capital Natural, Capital Humano y Participación de los Factores. Una Revisión de los Métodos de Medición del Crecimiento Económico” mimeo Universidad del Rosario-

Zuleta, H. and Young, A. T. (2007) "Labor's Shares Aggregate and Industry: Accounting for both in a model of unbalanced growth with induced innovation" Mimeo University of Mississippi. 
ANNEX

Table A. Capital income shares and wages (48 sectors)

\begin{tabular}{|c|c|c|c|c|c|c|}
\hline Sector & $\bar{\alpha}$ & $\operatorname{s.e}(\alpha)$ & $\bar{y}$ & s.e $(y)$ & $\Delta \alpha$ & $\Delta y$ \\
\hline Coffee & 0,043 & 0,012 & 0,020 & 0,004 & 0,017 & $-0,012$ \\
\hline Other agricultural products & 0,021 & 0,014 & 0,063 & 0,008 & $-0,030$ & $-0,024$ \\
\hline Living animals and animal products & 0,083 & 0,008 & 0,053 & 0,008 & 0,012 & $-0,019$ \\
\hline Forestry and logging & 0,063 & 0,037 & 0,002 & 0,001 & $-0,078$ & $-0,001$ \\
\hline Fishing and aquaculture & 0,165 & 0,030 & 0,004 & 0,001 & $-0,044$ & $-0,002$ \\
\hline Mining of coal and lignite & 0,754 & 0,088 & 0,009 & 0,003 & 0,016 & 0,001 \\
\hline Extraction of crude petroleum and natural gas & 0,763 & 0,079 & 0,030 & 0,009 & 0,017 & $-0,010$ \\
\hline Mining of metal ores & 0,302 & 0,028 & 0,007 & 0,003 & 0,009 & $-0,001$ \\
\hline Other mining and quarrying & 0,088 & 0,029 & 0,006 & 0,002 & 0,087 & 0,000 \\
\hline Electricity, gas, steam and air conditioning supply & 0,779 & 0,075 & 0,027 & 0,006 & 0,219 & 0,016 \\
\hline Water collection, treatment and supply, and sewerage & 0,640 & 0,083 & 0,010 & 0,001 & 0,235 & 0,004 \\
\hline Meat and fish & 0,171 & 0,070 & 0,008 & 0,001 & 0,058 & 0,001 \\
\hline Manufacture of other food products & 0,536 & 0,028 & 0,024 & 0,002 & 0,014 & $-0,005$ \\
\hline Sugar & 0,674 & 0,037 & 0,004 & 0,000 & 0,035 & $-0,001$ \\
\hline Manufacture of beverages & 0,625 & 0,053 & 0,012 & 0,001 & 0,172 & 0,000 \\
\hline Manufacture of tobacco products & 0,754 & 0,040 & 0,001 & 0,000 & 0,087 & $-0,001$ \\
\hline Manufacture of textiles & 0,444 & 0,171 & 0,006 & 0,005 & $-0,369$ & $-0,011$ \\
\hline Manufacture of wearing apparel & 0,364 & 0,056 & 0,010 & 0,002 & $-0,104$ & $-0,006$ \\
\hline Manufacture of leather and related products & 0,189 & 0,069 & 0,004 & 0,002 & $-0,020$ & $-0,005$ \\
\hline Manufacture of wood and of products of wood and cork & 0,378 & 0,053 & 0,002 & 0,000 & $-0,105$ & $-0,001$ \\
\hline Manufacture of paper and paper products & 0,568 & 0,087 & 0,005 & 0,001 & $-0,151$ & $-0,002$ \\
\hline Printing and reproduction of recorded media & 0,441 & 0,041 & 0,006 & 0,001 & 0,102 & 0,001 \\
\hline Manufacture of coke and refined petroleum products & 0,421 & 0,169 & 0,011 & 0,004 & 0,234 & 0,010 \\
\hline Manufacture of chemicals and chemical products & 0,641 & 0,038 & 0,021 & 0,002 & $-0,005$ & $-0,004$ \\
\hline Manufacture of rubber and plastics products & 0,591 & 0,031 & 0,008 & 0,001 & 0,046 & 0,001 \\
\hline Manufacture of other non-metallic mineral products & 0,484 & 0,053 & 0,010 & 0,001 & 0,171 & 0,001 \\
\hline Manufacture of furniture and other transport equipment & 0,181 & 0,069 & 0,004 & 0,001 & 0,235 & 0,001 \\
\hline $\begin{array}{l}\text { Manufacture of fabricated metal products, except machinery and } \\
\text { equipment }\end{array}$ & 0,383 & 0,054 & 0,010 & 0,002 & 0,137 & $-0,001$ \\
\hline Machinery and other electrical equipment & 0,334 & 0,075 & 0,006 & 0,001 & 0,104 & $-0,001$ \\
\hline Manufacture of other transport equipment & 0,366 & 0,128 & 0,004 & 0,001 & $-0,053$ & $-0,004$ \\
\hline Construction of buildings & 0,279 & 0,037 & 0,032 & 0,012 & 0,145 & 0,014 \\
\hline Civil engineering & 0,699 & 0,069 & 0,023 & 0,006 & 0,209 & 0,010 \\
\hline Retail trade & 0,209 & 0,022 & 0,083 & 0,011 & 0,076 & $-0,037$ \\
\hline Repair services & 0,029 & 0,006 & 0,014 & 0,001 & $-0,010$ & $-0,002$ \\
\hline Accommodation and food service activities & 0,144 & 0,114 & 0,021 & 0,005 & 0,493 & 0,015 \\
\hline Land transport and transport via pipelines & 0,024 & 0,014 & 0,038 & 0,003 & 0,021 & 0,005 \\
\hline Water transport & 0,244 & 0,157 & 0,002 & 0,001 & $-0,311$ & $-0,003$ \\
\hline Air transport & 0,574 & 0,072 & 0,005 & 0,001 & 0,213 & 0,002 \\
\hline Warehousing and support activities for transportation & 0,232 & 0,037 & 0,008 & 0,001 & 0,125 & 0,001 \\
\hline Postal and courier activities & 0,636 & 0,041 & 0,023 & 0,005 & 0,151 & 0,010 \\
\hline Financial service activities & 0,631 & 0,072 & 0,054 & 0,007 & 0,174 & 0,012 \\
\hline Real estate and rental housing & 0,718 & 0,088 & 0,089 & 0,010 & $-0,202$ & $-0,024$ \\
\hline Business services & 0,229 & 0,076 & 0,024 & 0,004 & 0,224 & 0,012 \\
\hline Housing services & 0,000 & 0,000 & 0,005 & 0,001 & 0,000 & $-0,002$ \\
\hline Advertising and market research & 0,378 & 0,093 & 0,023 & 0,008 & 0,248 & 0,015 \\
\hline Human health activities & 0,170 & 0,018 & 0,019 & 0,002 & 0,075 & 0,004 \\
\hline Other services & 0,213 & 0,121 & 0,015 & 0,002 & $-0,270$ & $-0,007$ \\
\hline Public administration & 0,220 & 0,016 & 0,138 & 0,025 & $-0,024$ & 0,052 \\
\hline
\end{tabular}

Source: Authors' estimations 
Table B. Value-added share and capital share correlations for 9 principal sectors

\begin{tabular}{|c|c|c|c|c|c|c|c|c|c|}
\hline$\alpha$ & Agriculture & Mining & Utilities & Manufacture & Construction & $\begin{array}{l}\text { Commerce, } \\
\text { restaurants } \\
\text { and hotels }\end{array}$ & $\begin{array}{c}\text { Transportation } \\
\text { and } \\
\text { communication }\end{array}$ & $\begin{array}{c}\text { Financial } \\
\text { Services }\end{array}$ & $\begin{array}{l}\text { Other } \\
\text { Services }\end{array}$ \\
\hline Mean & 0.052 & 0.618 & 0.743 & 0.487 & 0.467 & 0.180 & 0.274 & 0.625 & 0.230 \\
\hline Deviation & 0.005 & 0.096 & 0.076 & 0.030 & 0.067 & 0.021 & 0.047 & 0.045 & 0.008 \\
\hline \multirow{9}{*}{ 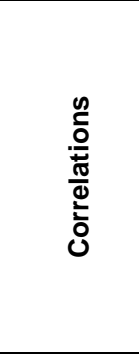 } & 1.000 & & & & & & & & \\
\hline & -0.190 & 1.000 & & & & & & & \\
\hline & -0.764 & 0.227 & 1.000 & & & & & & \\
\hline & -0.504 & 0.554 & 0.223 & 1.000 & & & & & \\
\hline & -0.348 & 0.230 & 0.749 & -0.222 & 1.000 & & & & \\
\hline & -0.564 & 0.121 & 0.548 & 0.518 & 0.366 & 1.000 & & & \\
\hline & -0.715 & 0.498 & 0.839 & 0.399 & 0.736 & 0.615 & 1.000 & & \\
\hline & 0.501 & -0.030 & -0.683 & 0.267 & -0.808 & -0.309 & -0.650 & 1.000 & \\
\hline & 0.046 & -0.096 & 0.088 & 0.028 & 0.114 & 0.171 & 0.208 & -0.115 & 1.000 \\
\hline Change & -0.009 & 0.014 & 0.230 & 0.042 & 0.174 & 0.086 & 0.117 & -0.068 & 0.005 \\
\hline$y$ & Agriculture & Mining & Utilities & Manufacture & Construction & $\begin{array}{l}\text { Commerce. } \\
\text { restaurants } \\
\text { and hotels }\end{array}$ & $\begin{array}{c}\text { Transportation } \\
\text { and } \\
\text { communication }\end{array}$ & $\begin{array}{c}\text { Financial } \\
\text { Services }\end{array}$ & $\begin{array}{l}\text { Other } \\
\text { Services }\end{array}$ \\
\hline \multirow{2}{*}{$\begin{array}{l}\text { Mean } \\
\text { Deviation }\end{array}$} & 0.141 & 0.052 & 0.037 & 0.156 & 0.055 & 0.118 & 0.075 & 0.167 & 0.199 \\
\hline & 0.020 & 0.013 & 0.007 & 0.013 & 0.014 & 0.009 & 0.004 & 0.014 & 0.033 \\
\hline \multirow{9}{*}{ 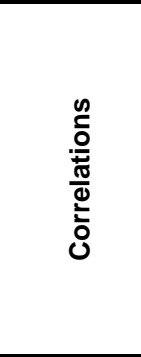 } & 1.000 & & & & & & & & \\
\hline & 0.152 & 1.000 & & & & & & & \\
\hline & -0.878 & 0.109 & 1.000 & & & & & & \\
\hline & 0.784 & 0.635 & -0.496 & 1.000 & & & & & \\
\hline & -0.004 & -0.678 & -0.188 & -0.221 & 1.000 & & & & \\
\hline & 0.855 & -0.234 & -0.882 & 0.520 & 0.408 & 1.000 & & & \\
\hline & -0.611 & 0.033 & 0.829 & -0.310 & -0.095 & -0.701 & 1.000 & & \\
\hline & -0.129 & -0.881 & -0.262 & -0.602 & 0.647 & 0.266 & -0.369 & 1.000 & \\
\hline & -0.872 & -0.045 & 0.780 & -0.759 & -0.390 & -0.893 & 0.549 & 0.003 & 1.000 \\
\hline Change & -0.058 & -0.010 & 0.020 & -0.028 & 0.023 & -0.024 & 0.016 & 0.000 & 0.062 \\
\hline
\end{tabular}

Source: Authors' estimations 
Table C. Factor Shares Determinants

\begin{tabular}{|c|c|c|c|c|c|}
\hline Value added & $\begin{array}{l}1.51 \mathrm{e}-08 * * \\
(7.21 \mathrm{e}-09)\end{array}$ & Log(RFP) sector 21 & $\begin{array}{c}-0.443^{\star \star \star} \\
(0.163)\end{array}$ & Log(RFP) sector 42 & $\begin{array}{c}-0.633^{* * *} \\
(0.173)\end{array}$ \\
\hline Log(RFP) sector 1 & $\begin{array}{c}0.0819 * * * \\
(0.0186)\end{array}$ & Log(RFP) sector 22 & $\begin{array}{l}0.273^{\star * \star} \\
(0.0564)\end{array}$ & Log(RFP) sector 43 & $\begin{array}{l}0.428 * \star \star \\
(0.0829)\end{array}$ \\
\hline Log(RFP) sector 2 & $\begin{array}{l}-0.143^{\star \star \star} \\
(0.0245)\end{array}$ & Log(RFP) sector 23 & $\begin{array}{l}1.370 \star \star \star \\
(0.168)\end{array}$ & Log(RFP) sector 44 & $\begin{array}{c}-0.00103^{*} \\
(0.000558)\end{array}$ \\
\hline Log(RFP) sector 3 & $\begin{array}{c}0.0164 \\
(0.0225)\end{array}$ & Log(RFP) sector 24 & $\begin{array}{c}0.0818 \\
(0.0896)\end{array}$ & Log(RFP) sector 45 & $\begin{array}{l}0.594^{\star \star \star} \\
(0.119)\end{array}$ \\
\hline Log(RFP) sector 4 & $\begin{array}{l}-0.256^{\star \star \star} \\
(0.0348)\end{array}$ & Log(RFP) sector 25 & $\begin{array}{c}0.150 \star \star \\
(0.0692)\end{array}$ & Log(RFP) sector 46 & $\begin{array}{l}0.0820^{\star} \\
(0.0467)\end{array}$ \\
\hline Log(RFP) sector 5 & $\begin{array}{l}-0.184^{\star \star *} \\
(0.0321)\end{array}$ & Log(RFP) sector 26 & $\begin{array}{l}0.417^{\star * *} \\
(0.0518)\end{array}$ & Log(RFP) sector 47 & $\begin{array}{c}-0.906^{\star \star *} \\
(0.135)\end{array}$ \\
\hline Log(RFP) sector 6 & $\begin{array}{c}0.457^{\star \star \star} \\
(0.167)\end{array}$ & Log(RFP) sector 27 & $\begin{array}{l}0.489 * \star \star \\
(0.114)\end{array}$ & Log(RFP) sector 48 & $\begin{array}{l}-0.351^{\star} \\
(0.181)\end{array}$ \\
\hline Log(RFP) sector 7 & $\begin{array}{l}0.303^{\star *} \\
(0.135)\end{array}$ & Log(RFP) sector 28 & $\begin{array}{l}0.420^{\star \star \star} \\
(0.0987)\end{array}$ & Constant & $\begin{array}{c}-0.971^{\star \star \star} \\
(0.240)\end{array}$ \\
\hline Log(RFP) sector 8 & $\begin{array}{l}0.129 * \star \star \\
(0.0412)\end{array}$ & Log(RFP) sector 29 & $\begin{array}{l}0.280^{* *} \\
(0.140)\end{array}$ & & \\
\hline Log(RFP) sector 9 & $\begin{array}{c}0.142^{\star} \\
(0.0754)\end{array}$ & Log(RFP) sector 30 & $\begin{array}{c}0.383 \\
(0.234)\end{array}$ & & \\
\hline Log(RFP) sector 10 & $\begin{array}{l}0.394^{\star \star \star} \\
(0.107)\end{array}$ & Log(RFP) sector 31 & $\begin{array}{c}0.0195 \\
(0.0746)\end{array}$ & & \\
\hline Log(RFP) sector 11 & $\begin{array}{l}0.497^{\star \star \star} \\
(0.0764)\end{array}$ & Log(RFP) sector 32 & $\begin{array}{l}0.272^{\star \star} \\
(0.119)\end{array}$ & & \\
\hline Log(RFP) sector 12 & $\begin{array}{c}-0.0125 \\
(0.117)\end{array}$ & Log(RFP) sector 33 & $\begin{array}{c}0.113^{\star *} \\
(0.0562)\end{array}$ & & \\
\hline Log(RFP) sector 13 & $\begin{array}{c}0.0977 \\
(0.0707)\end{array}$ & Log(RFP) sector 34 & $\begin{array}{c}-0.0347^{\star *} \\
(0.0136)\end{array}$ & & \\
\hline Log(RFP) sector 14 & $\begin{array}{l}0.210^{\star \star \star} \\
(0.0732)\end{array}$ & Log(RFP) sector 35 & $\begin{array}{l}0.374^{\star \star} \\
(0.156)\end{array}$ & & \\
\hline Log(RFP) sector 15 & $\begin{array}{l}0.292^{\star \star \star} \\
(0.0946)\end{array}$ & Log(RFP) sector 36 & $\begin{array}{c}0.0352 \\
(0.0325)\end{array}$ & & \\
\hline Log(RFP) sector 16 & $\begin{array}{l}0.224 \star \star \star \\
(0.0664)\end{array}$ & Log(RFP) sector 37 & $\begin{array}{c}-0.927^{\star \star \star} \\
(0.188)\end{array}$ & & \\
\hline Log(RFP) sector 17 & $\begin{array}{c}-1.041^{\star \star \star} \\
(0.283)\end{array}$ & Log(RFP) sector 38 & $\begin{array}{c}0.550 \star \star \star \\
(0.104)\end{array}$ & & \\
\hline Log(RFP) sector 18 & $\begin{array}{l}-0.197 \\
(0.125)\end{array}$ & Log(RFP) sector 39 & $\begin{array}{l}0.236^{\star \star \star} \\
(0.0653)\end{array}$ & & \\
\hline Log(RFP) sector 19 & $\begin{array}{l}0.0837 \\
(0.159)\end{array}$ & Log(RFP) sector 40 & $\begin{array}{c}0.164 \\
(0.106)\end{array}$ & & \\
\hline Log(RFP) sector 20 & $\begin{array}{l}-0.241^{\star \star *} \\
(0.0828)\end{array}$ & Log(RFP) sector 41 & $\begin{array}{l}0.476^{\star \star \star} \\
(0.0997)\end{array}$ & & \\
\hline
\end{tabular}

Robust standard errors in parentheses

*** $\mathrm{p}<0.01, * * \mathrm{p}<0.05, * \mathrm{p}<0.1$

Source: Authors' estimations 
Table D. Factor Shares Determinants- Dynamic Panel

\begin{tabular}{|c|c|c|c|}
\hline & (1) & (2) & (3) \\
\hline Diff Alpha (-1) & $\begin{array}{l}0.619^{* \star \star} \\
(0.0654)\end{array}$ & $\begin{array}{l}0.644^{\star \star \star} \\
(0.0663)\end{array}$ & $\begin{array}{l}0.638^{\star * \star} \\
(0.0709)\end{array}$ \\
\hline Diff Value Added & $\begin{array}{l}\text { 3.83E-08 } \\
(2.58 \mathrm{E}-08) \\
\end{array}$ & $\begin{array}{c}4.3 \mathrm{E}-08^{*} \\
(2.58 \mathrm{E}-08)\end{array}$ & $\begin{array}{l}4.87 \mathrm{E}-08^{\star} \\
(2.77 \mathrm{E}-08)\end{array}$ \\
\hline Diff Value Added (-1) & $\begin{array}{l}-2.17 \mathrm{E}-08 \\
(1.61 \mathrm{E}-08)\end{array}$ & $\begin{array}{l}-3.1 E-08^{\star} \\
(1.81 E-08)\end{array}$ & $\begin{array}{r}-3.08 \mathrm{E}-08^{*} \\
(1.8 \mathrm{E}-08) \\
\end{array}$ \\
\hline Diff Interest Rate & $\begin{array}{c}0.0027 \\
(0.0605)\end{array}$ & & \\
\hline Diff Interest Rate (-1) & $\begin{array}{l}-0.209^{\star \star \star} \\
(0.0782)\end{array}$ & & \\
\hline Diff log wage & $\begin{array}{l}-0.0531 \\
(0.0477)\end{array}$ & & \\
\hline Diff log wage(-1) & $\begin{array}{l}0.094^{\star \star \star} \\
(0.0361)\end{array}$ & & \\
\hline Diff log relative prices & & $\begin{array}{l}-0.0256 \\
(0.0504)\end{array}$ & \\
\hline Diff log relative prices $(-1)$ & & $\begin{array}{l}0.0856^{\star \star \star} \\
(0.0390)\end{array}$ & \\
\hline $\begin{array}{l}\text { Diff Log(relative factor prices) } \\
\text { Agriculture and Mining }\end{array}$ & & & $\begin{array}{l}-0.112^{\star \star} \\
(0.0560)\end{array}$ \\
\hline $\begin{array}{l}\text { Diff Log(relative factor prices) (-1) } \\
\text { Agriculture and Mining }\end{array}$ & & & $\begin{array}{c}0.0538 \\
(0.0521) \\
\end{array}$ \\
\hline Diff Log(relative factor prices) Utilities & & & $\begin{array}{c}0.1718 \\
(0.1095)\end{array}$ \\
\hline $\begin{array}{l}\text { Diff Log(relative factor prices) (-1) } \\
\text { Utilities }\end{array}$ & & & $\begin{array}{l}-0.244^{\star \star *} \\
-0.0743\end{array}$ \\
\hline $\begin{array}{l}\text { Diff Log(relative factor prices) } \\
\text { Manufacturing }\end{array}$ & & & $\begin{array}{c}0.0109 \\
(0.1084)\end{array}$ \\
\hline $\begin{array}{l}\text { Diff Log(relative factor prices) (-1) } \\
\text { Manufacturing }\end{array}$ & & & $\begin{array}{l}0.1493^{* *} \\
(0.0683)\end{array}$ \\
\hline $\begin{array}{l}\text { Diff Log(relative factor prices) } \\
\text { Construction }\end{array}$ & & & $\begin{array}{l}-0.189 * \star \\
(0.0799)\end{array}$ \\
\hline $\begin{array}{l}\text { Diff Log(relative factor prices) (-1) } \\
\text { Construction }\end{array}$ & & & $\begin{array}{l}-0.0142 \\
(0.0663)\end{array}$ \\
\hline $\begin{array}{l}\text { Diff Log(relative factor prices) Trade } \\
\text { and Transportation }\end{array}$ & & & $\begin{array}{c}0.0053 \\
(0.0470)\end{array}$ \\
\hline $\begin{array}{l}\text { Diff Log(relative factor prices) (- } \\
\text { 1)Trade and Transportation }\end{array}$ & & & $\begin{array}{c}0.1018 \\
(0.0682)\end{array}$ \\
\hline $\begin{array}{l}\text { Diff Log(relative factor prices) } \\
\text { Financial services }\end{array}$ & & & $\begin{array}{l}-0.1573 \\
(0.1802)\end{array}$ \\
\hline $\begin{array}{l}\text { Diff Log(relative factor prices) (-1) } \\
\text { Financial services }\end{array}$ & & & $\begin{array}{r}0.0231 \\
-0.0438\end{array}$ \\
\hline $\begin{array}{l}\text { Diff Log(relative factor prices) Social } \\
\text { services }\end{array}$ & & & $\begin{array}{l}-0.0118 \\
(0.0623)\end{array}$ \\
\hline $\begin{array}{l}\text { Diff Log(relative factor prices) (-1) } \\
\text { Social services }\end{array}$ & & & $\begin{array}{c}0.0683 \\
(0.0752)\end{array}$ \\
\hline Constant & $\begin{array}{c}0.0005 \\
(0.0014)\end{array}$ & $\begin{array}{c}0.0006 \\
(0.0014)\end{array}$ & $\begin{array}{c}0.0005 \\
(0.0015)\end{array}$ \\
\hline $\begin{array}{l}\text { Wald Test } \\
\text { P-value }\end{array}$ & $\begin{array}{c}190.35 \\
0.00\end{array}$ & $\begin{array}{c}193.12 \\
0.00\end{array}$ & $\begin{array}{c}430.37 \\
0.00\end{array}$ \\
\hline
\end{tabular}

Robust standard errors in parentheses

*** $\mathrm{p}<0.01, * * \mathrm{p}<0.05, * \mathrm{p}<0.1$

Source: Authors' estimations 